\title{
Genetic Relatedness Among the Typhus Group of Rickettsiae
}

\author{
WILLIAM F. MYERS AND CHARLES L. WISSEMAN, JR. \\ Department of Microbiology, University of Maryland, School of Medicine, Baltimore, Maryland 21201
}

The taxonomy of the typhus biogroup (Rickettsia prowazekii and $R$. mooseri [R. typhi]) of the genus Rickettsia and Rochalimaea quintana has been studied on the basis of the guanine plus cytosine content of the respective deoxyribonucleic acids (DNAs), the genome size, and the degree of DNA-DNA hybridization. The previously published guanine plus cytosine values for certain strains are confirmed, and the guanine plus cytosine values are described for some additional strains in each species. The genome sizes of four strains of $R$. prowazekii, three strains of $R$. mooseri, and two strains of $R$. quintana were very similar and averaged approximately $10^{9}$ daltons. The various strains within the species boundaries hybridized at nearly the $100 \%$ level. The DNAs of various strains of $R$. prowazekii hybridized with the DNAs of various strains of $R$. mooseri rather consistently at the level of 70 to $77 \%$. The DNAs of two strains of Rochalimaea quintana hybridized with those of $R$. prowazekii Breinl and $R$. mooseri Wilmington in the range of 25 to $33 \%$.

The typhus group of rickettsiae is one of the biogroups that comprise the genus Rickettsia, the others being the spotted fever and scrub typhus groups. The typhus group contains three recognized species: $R$. prowazekii, $R$. mooseri (R. typhi), and R. canada. The classification is based on strong serological cross-reactions within the group as well as on other biological characteristics (41). A common guanine plus cytosine $(\mathrm{G}+\mathrm{C})$ content of deoxyribonucleic acid (DNA) has been demonstrated recently among strains of the typhus biogroup (37). Within the typhus group, recent studies of protein profiles have generally supported the established taxonomy based on serological and biological differences $(13,14,19)$. This report provides additional information on the taxonomy of the group based on the $\mathrm{G}+\mathrm{C}$ content of DNA, genome size, and DNA-DNA hybridization. Established strains and recent isolates of $R$. prowazekii and $R$. mooseri of the typhus biogroup are compared with each other as well as with two strains of Rochalimaea quintana.

\section{MATERIALS AND METHODS}

Rickettsial strains. The designations, sources, passage histories, and other pertinent information on the strains used in this study are presented in Table 1.

Reagents. Reagent grade liquefied phenol (Fisher Scientific Co., Pittsburgh, Pa.) was freshly distilled over metallic zinc into water. The phenol was stored in a brown bottle under nitrogen. Before use, the phenol was neutralized by adding $1 / 50$ volume of 1.0 M sodium phosphate buffer, $\mathrm{pH}$ 6.8. Ribonuclease (Worthington Biochemical Corp., Freehold, N.J.) was dissolved in $0.05 \mathrm{M}$ sodium phosphate buffer ( $\mathrm{pH}$ 6.8) and heated at $80^{\circ} \mathrm{C}$ for $10 \mathrm{~min}$ to inactivate any possible deoxyribonuclease activity in the preparation.
Growth and purification of rickettsiae. The various rickettsial agents had been previously plaque purified in these laboratories (C. L. Wisseman, Jr., et al., unpublished data) to rid the cultures of extraneous agents. Seed pools of rickettsiae were then built up in Cofal/Marek-negative eggs (SPAFAS, Inc., Norwich, Conn.) and stored $\left(-70^{\circ} \mathrm{C}\right)$ as $20 \%$ yolk sac homogenates in brain heart infusion medium. For rickettsial production, 6-day-old conventional eggs (Truslow Farms, Chestertown, Md.) were inoculated via the yolk sac route with seed pool inoculum diluted so that 30 to $50 \%$ of the eggs were killed in 7 to 8 days. Only live embryos were harvested. The yolk sacs were aseptically removed, blended, and diluted in brain heart infusion broth to a $20 \%$ (wt/vol) concentration. They were then shell frozen in an alcohol-Dry Ice mixture and stored at $-70^{\circ} \mathrm{C}$ until needed.

The rickettsiae were freed of host cell contaminants by methods developed and adapted in these laboratories and in use for several years (C. L. Wisseman, Jr., et al., unpublished data). This included an initial purification and concentration of the crude yolk sac homogenate by a sucrose batch method which removed about $90 \%$ of the contaminants, followed by a flocculation of the remaining host cell materials by a combination of albumin (2) and anti-yolk sac serum (21) precipitation, and finally two cycles of gradient separation, in this instance a modification of the Renografin gradient of Cahn and Fox (9) as adapted by Weiss et al. $(14,40)$ to rickettsiae. The purified rickettsiae were suspended finally in $1 \times$ saline-sodium citrate (SSC) (20), shell frozen in a Dry Ice-alcohol bath, and stored at $-70^{\circ} \mathrm{C}$ until needed.

Growth and purification of $\boldsymbol{R}$. quintana. The Fuller (ATCC VR-358) and Heliodoro (courtesy of J. W. Vinson, Harvard University School of Public Health, Boston, Mass.) strains of $R$. quintana were stored as seed pools in brain heart infusion broth at $-70^{\circ} \mathrm{C}$ until needed. When cells were desired, an ampoule was quickly thawed, and several drops were placed onto each of a series of plates of Trypticase soy 
TABLE 1. Source, passage history, and other pertinent information on the strains employed in this study

\begin{tabular}{|c|c|c|c|c|}
\hline Organism/strain & Source & Passage history $^{\alpha}$ & $\begin{array}{l}\text { Plaque puri- } \\
\text { fied }\end{array}$ & Reference \\
\hline \multicolumn{5}{|l|}{ Rickettsia prowazekii } \\
\hline Breinl & Human & E155/TC3/E3 & Yes & 44 \\
\hline Madrid E & Human & CRD $-3^{b} / \mathrm{TC} 3 / \mathrm{E} 4$ & Yes & 11 \\
\hline Bur X-16 & Human & $\mathrm{TC} 5 / \mathrm{E} 2$ & Yes & $-^{c}$ \\
\hline $\mathrm{GV}-\mathrm{F} 12^{d}$ & Flying squirrel & E7 & No & 4 \\
\hline \multicolumn{5}{|c|}{ Rickettsia mooseri (R. typhi) } \\
\hline Wilmington & Rat & E42/TC3/E3 & Yes & 28 \\
\hline Pak NA-18 & Rat & GP/TC5/E3 & Yes & $-^{c}$ \\
\hline Ethio AZ-306 & Rat & TC5/E3 & Yes & $-^{c}$ \\
\hline \multicolumn{5}{|l|}{ Rochalimaea quintana } \\
\hline Fuller & Human & BA9 & Yes & 39 \\
\hline Heliodoro & Human & BA7 & No & 38 \\
\hline
\end{tabular}

"Abbreviations: E, Yolk sac passage; TC, tissue culture plaque purification passage; GP, guinea pig passage; BA, blood agar passage.

${ }^{b}$ Experimental vaccine lot CRD-3 (C. L. Wisseman, Jr., unpublished data).

'C. L. Wisseman, Jr., et al., unpublished data.

${ }^{d}$ Furnished by F. M. Bozeman, Bureau of Biologics, Food and Drug Administration, Bethesda, Md.

agar with $10 \%$ sheep blood (BBL Microbiology Systems, Cockeysville, Md.). The inoculum was spread on each plate with a sterile glass rod. The plates were incubated at $35^{\circ} \mathrm{C}$ for 3 to 4 days in an atmosphere of $95 \%$ air $-5 \% \mathrm{CO}_{2}$ and a relative humidity of 90 to $95 \%$ to obtain a confluent lawn. The cells were harvested from each plate by emulsifying the growth in 3 to $4 \mathrm{ml}$ of $1 \times$ SSC. Any agar particles were first removed by low-speed centrifugation $(200 \times g, 5 \mathrm{~min})$ followed by centrifugation at $12,000 \times g$ for $15 \mathrm{~min}$. The cell suspension was washed an additional two times in $1 \times$ SSC and finally resuspended in $1 \times$ SSC to an optical density (OD) of 2.00 at $440 \mathrm{~nm}$ and with a 1-cm light path. Bacteriological criteria for $R$. quintana included (i) the inability to grow on the blood agar medium employed when incubated in the absence of $\mathrm{CO}_{2}$, (ii) the inability to grow on a Trypticase soy agar without blood enrichment, (iii) a generation time on the order of 10 to $12 \mathrm{~h}$, and (iv) appropriate morphology and tinctorial properties, i.e., staining well with the Giménez basic fuchsin stain but poorly with the Gram stain.

Purification and shearing of DNA. The DNA extraction and purification procedure was basically that described by Thomas et al. (36). Pronase (1 mg/ $\mathrm{ml}$ ) was added to the rickettsial suspension $(O D=2.0$ at $440 \mathrm{~nm}$ and $1-\mathrm{cm}$ light path) followed by $0.2 \%$ sodium dodecyl sulfate. 'The mixture was incubated at $37^{\circ} \mathrm{C}$ for $7 \mathrm{~h}$. The cell lysate was extracted with phenol for $30 \mathrm{~min}$, and the DNA was precipitated from the aqueous phase with two volumes of chilled ethyl alcohol $(95 \%)$. The partially purified DNA was dissolved in $0.1 \times \mathrm{SSC}$ and then dialyzed against $0.05 \mathrm{M}$ sodium phosphate buffer (pH 6.8). Ribonuclease $(50 \mu \mathrm{g} / \mathrm{ml}$ ) was added after dialysis, and the solution was incubated for $2 \mathrm{~h}$ at $37^{\circ} \mathrm{C}$. The DNA was then adsorbed onto hydroxyapatite (DNA grade, Bio-Rad Laboratories, Richmond, Calif., $0.20 \mathrm{M}$ sodium phosphate buffer, $\mathrm{pH} 6.8$ ), followed later by elution $(0.40 \mathrm{M}$ sodium phosphate buffer, $\mathrm{pH} 6.8$ ) according to the procedure suggested by Thomas et al. (36). The DNA solution was then dialyzed overnight against $0.1 \times \mathrm{SSC}$. The DNA was sheared in a Ribi cell fractionator at $21,000 \mathrm{lb} / \mathrm{in}^{2}$ at a rate of $3 \mathrm{ml} / \mathrm{min}(20)$, and the sheared DNA was concentrated under vacuum (rotating flask) to an OD in excess of $2.0(260 \mathrm{~nm}, 1-\mathrm{cm}$ light path). The DNA was then dialyzed against $2 \times \mathrm{SSC}$, and the resultant product was shell frozen in an alcohol-Dry Ice bath and stored at $-70^{\circ} \mathrm{C}$ in flame-sealed ampoules.

Determination of sheared DNA fragment length by electron microscopy. The sheared DNA was spread as a film using the Kleinschmidt-formamide technique (23). DNA fragments were picked up on copper grids coated with a collodion carbon film, which were then rotary-shadowed in an Edwards evaporator. The shadowing material was $17 \mathrm{~mm}$ of platinum-palladium wire which was burned at $5 \mathrm{~cm}$ from the specimen and at a height of $4 \mathrm{~mm}$. The photographic negative images of the DNA fragments were projected in a darkened room onto large sheets of paper ( 3 by 4 feet [ca. 0.91 by $1.22 \mathrm{~m}$ ]) to give DNA fragments averaging 5 to $6 \mathrm{~cm}$. The fragments were traced over with a felt-tipped marker pen, and the fragment lengths were then determined by using a map-measuring tool. The mean and standard deviation values so obtained were converted to true lengths by multiplying by the overall magnification factor. DNA fragment length was converted to daltons according to the Watson-Crick B configuration of double-stranded DNA (24). Assuming these conditions, the molar linear density is $1.91 \times 10^{10}$ daltons $/ \mathrm{cm}$.

Determination of DNA concentration and purity. The DNA content was determined by the Burton (8) modification of the diphenylamine reaction. Ribonucleic acid and protein levels in the DNA samples were assayed by the methods of Meijbaum (30) and Lowry et al. (25), respectively.

Determination of $G+C$ content of DNA. The $\mathrm{G}+\mathrm{C}$ content (moles percent) of DNA was determined by the method of Marmur and Doty (27). All assays were performed in a Gilford spectrophotometer 2400- 
2 equipped with a thermoprogrammer unit and a reference compensator. After obtaining base-line optical values at $25^{\circ} \mathrm{C}$, the temperature was raised to ca. $10^{\circ} \mathrm{C}$ below the melting point and maintained there for $10 \mathrm{~min}$ to allow temperature equilibration. The temperature rise was then set for $0.25^{\circ} \mathrm{C} / \mathrm{min}$, and temperature and OD changes were recorded over a $20^{\circ} \mathrm{C}$ span.

Determination of genome size. Genome size determinations were made by using the renaturation rate method of Gillis et al. (20). The DNA was diluted in $2 \times \mathrm{SSC}$ so that the rate of renaturation remained linear for approximately $30 \mathrm{~min}$. Each determination was done with duplicate samples. The blank was diluted with adenine to the same OD as the DNA. The DNA was taken rapidly to a temperature ca. $10^{\circ} \mathrm{C}$ above its melting point and maintained there for 15 min. The temperature was then reduced rapidly $(<2$ $\mathrm{min}$ ) to the optimal renaturation temperature, determined according to the equation: $T_{o r}=1.24 T_{m}-38.8$. The samples were maintained at this latter temperature during the subsequent $30 \mathrm{~min}$. The rate of renaturation is inversely proportional to the original molecular weight of the unsheared DNA. The reaction rate, $k$, is equal to $v / c^{2}$, where $v$ is the decrease in absorbance per minute $(260 \mathrm{~nm})$ and $c$ is the DNA concentration expressed as millimolar nucleotide pairs. DNA molecular weight is related to $k$ by the equation: molecular weight $\times 10^{-7}=\{98.37-[0.91 \times$ $\%(\mathrm{G}+\mathrm{C})\rceil\} / k$.

Measurement of DNA-DNA hybridization. The procedure followed (16) is, in principle, very similar to that involved in determining genome size. Four cuvettes are required. The adenine blank and the two DNA samples to be compared were set up as described in the section on genome size. In addition, a cuvette contained a 1:1 mixture of the two DNAs to be compared. In all other respects, the analytical procedure was the same as that described under genome size determination. The degree of hybridization, $D$, is determined according to the equation: $D=\left[4 V_{m}-\left(V_{\mathrm{A}}\right.\right.$ $\left.+V_{\mathrm{B}}\right) / 2 \sqrt{V_{\mathrm{A}} V_{\mathrm{B}}}$, where $V_{m}, V_{\mathrm{A}}$, and $V_{\mathrm{B}}$ are the decrease in absorbance per minute $(260 \mathrm{~nm})$ in the DNA mixture, sample A, and sample $B$, respectively. When hybridization experiments were performed between $R$. prowazekii or $R$. mooseri and $R$. quintana, whose optimal renaturation temperatures are 62 and $66^{\circ} \mathrm{C}$, respectively, an intermediate temperature of $64^{\circ} \mathrm{C}$ was chosen.

\section{RESULTS}

Chemical purity and fragment length of DNA preparations. The levels of protein and ribonucleic acid in our DNA samples were below the levels of detectability with our assay procedures and were less than $1 \%$ of the DNA concentrations.

Two sheared DNA preparations of $R$. prowa$z e k i i$ Breinl and one of $R$. mooseri Wilmington were assayed by electron microscopy for DNA fragment size. The results were $2.1 \pm 1.0 \times 10^{5}$ daltons (255 fragments), $2.9 \pm 1.2 \times 10^{5}$ daltons (408 fragments), and $2.5 \pm 1.1 \times 10^{5}$ daltons (206 fragments), respectively.
$\mathrm{G}+\mathrm{C}$ content of DNA. Table 2 presents the $\mathrm{G}+\mathrm{C}$ content of the DNA extracted from strains of several rickettsial species. The data shown for the Breinl and Madrid E strains of $R$. prowa$z e k i i$ and the Wilmington strain of $R$. mooseri confirm the previous results obtained by several investigators $(37,43)$; the results for the Burundi and flying squirrel strains of $R$. prowazekii and the Pakistan and Ethiopian strains of $R$. mooseri are new data.

Our value for the $\mathrm{G}+\mathrm{C}$ content for the Fuller strain of $R$. quintana is consistent with the previously published value (37); the similar $\mathrm{G}+\mathrm{C}$ value for the Heliodoro strain of $R$. quintana is new information. Escherichia coli K-12 DNA was analyzed for comparison. The $\mathrm{G}+\mathrm{C}$ values of all DNA preparations, both rickettsial and $E$. coli, agreed well with the values previously published $(27,37,43)$. The new data are consistent with groupings based on other data.

Genome size. The molecular weights of the DNAs of the four strains of $R$. prowazekii and the three strains of $R$. mooseri appear to be the same: approximately $1.1 \times 10^{9}$. The genome size data on $R$. quintana Fuller and Heliodoro gave a value $\left(1.0 \times 10^{9}\right.$ daltons) slightly lower than that obtained for the typhus group, but the differences may not be significant. The genome size obtained for the Fuller strain is in good agreement with a previously published value for this strain (22). E. coli $\mathrm{K}-12$, as a reference organism, gave the appropriate value, $2.4 \times 10^{9}$ daltons, consistent with published data (20). The genome in the rickettsiae tested, as a group, is thus seen to be about $45 \%$ of that of $E$. coli.

DNA-DNA hybridizations. Table 3 presents the degree of hybridization obtained under stringent renaturation conditions. When the DNAs of various strains recognized as belonging to the same species on the basis of serological criteria were hybridized, the values were invariably over $90 \%$ and were usually close to $100 \%$. When the DNAs of various strains of $R$. prowazekii and $R$. mooseri were hybridized across the species line, the values rather consistently fell between 70 and $77 \%$. The DNAs of $R$. quintana Fuller and Heliodoro hybridized against the DNAs of several strains of $R$. prowazekii and $R$. mooseri gave considerably lower values (25 to $33 \%$ ).

\section{DISCUSSION}

Information on the molecular weight of a DNA can be obtained from the rate of reassociation of the complementary strands. Britten and Kohne (7) showed that the rate of reassociation of bacterial or viral DNAs is directly proportional to the size of the genome. They expressed this rate as the $C_{0} t_{0.5}$, the concentration of DNA 
TABLE 2. G+C content of the DNA and genome size of strains of $R$. prowazekii, $R$. mooseri, $R$. quintana, and E. coli

\begin{tabular}{|c|c|c|c|c|c|c|}
\hline \multirow{3}{*}{ Biogroup/strain } & \multicolumn{2}{|c|}{$\mathrm{G}+\mathrm{C}$ content $(\mathrm{mol} \%)$} & \multicolumn{4}{|c|}{ Genome size } \\
\hline & \multirow{2}{*}{$\begin{array}{l}\text { Experimen- } \\
\mathrm{tal}^{a}\end{array}$} & \multirow{2}{*}{ Published $^{b}$} & \multirow{2}{*}{$\begin{array}{l}\text { DNA } \\
\text { prepn }\end{array}$} & \multirow{2}{*}{$\begin{array}{l}\text { No. of } \\
\text { runs }\end{array}$} & \multicolumn{2}{|c|}{ mol wt $\left(\times 10^{-i}\right)( \pm \mathrm{SD})^{r}$} \\
\hline & & & & & Experimental $^{a}$ & Published $^{b}$ \\
\hline \multicolumn{7}{|l|}{ Rickettsia prowazekii } \\
\hline \multirow[t]{2}{*}{ Breinl } & 29.0 & $29.0(37)^{d}$ & 1 & 5 & $106 \pm 6.6$ & \\
\hline & & & 2 & 16 & $112 \pm 9.2$ & \\
\hline Madrid E & 28.5 & $29.3(37)$ & 1 & 1 & (111) & \\
\hline Burundi (V-16) & 29.7 & & 1 & 6 & $108 \pm 6.7$ & \\
\hline Flying squirrel (GV-F-12) & 29.5 & & 1 & 8 & $114 \pm 5.8$ & \\
\hline \multicolumn{7}{|l|}{ Rickettsia mooseri (R. typhi) } \\
\hline Wilmington & 29.0 & $29.3(37,43)$ & 1 & 17 & $109 \pm 7.9$ & \\
\hline Pakistan (NA-18) & 28.5 & & 1 & 8 & $107 \pm 6.1$ & \\
\hline Ethiopian (Eth-306) & 29.0 & & 1 & 3 & $107 \pm 4.0$ & \\
\hline \multicolumn{7}{|l|}{ Rochalimaea quintana } \\
\hline Fuller & 39.3 & $38.8(37)$ & 1 & 6 & $101 \pm 3.5$ & $93(22)^{d}$ \\
\hline Heliodoro & 39.8 & & 1 & 5 & $105 \pm 2.4$ & \\
\hline \multicolumn{7}{|l|}{ Escherichia coli } \\
\hline $\mathrm{K}-12$ & 51.7 & & 1 & 6 & $241 \pm 13$ & $245(20)$ \\
\hline
\end{tabular}

TABLE 3. DNA-DNA hybridizations between strains of $R$. prowazekii, $R$. mooseri, and $R$. quintana

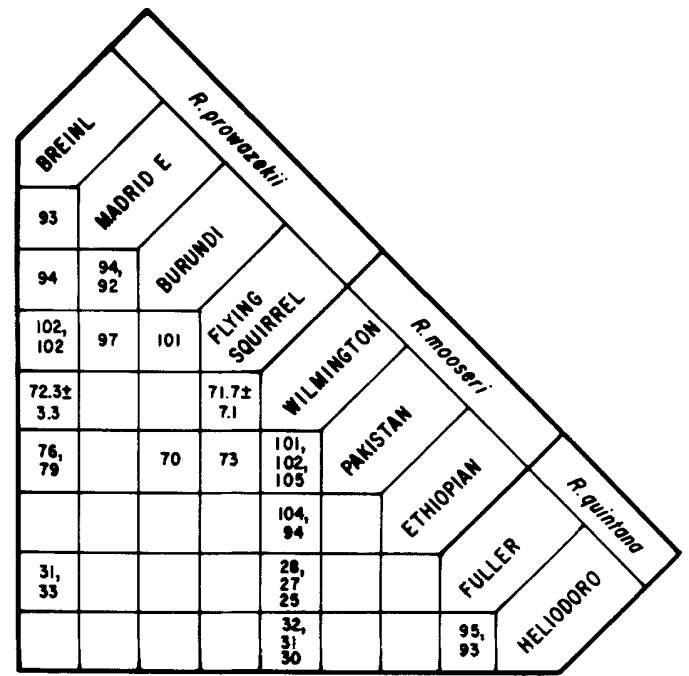

in moles of nucleotide per liter times the time in seconds required for $50 \%$ reassociation. This relationship exists because the vast majority of the cistrons of a viral or bacterial DNA is composed of unique base sequences. As the result of these basic studies on the kinetics of renaturation by
Britten and Kohne (7) and Wetmur and Davidson (42), a number of investigators have applied these concepts to determining the genome sizes of a variety of microorganisms $(1,10,22,34)$. This is readily accomplished with a recording spectrophotometer. The formation of double- 
stranded complexes between complementary strands of the DNA is observed by the hypochromic shift. The rate of reassociation is determined by the rate of change in absorbance.

Gillis et al. (20) introduced a modified renaturation rate method for the determination of the molecular weight of genome DNA which was based on initial optical renaturation rate measurements of precisely known concentrations of fragmented DNA. The exact conditions and the effects of DNA concentration, renaturation time, size of DNA fragments, buffer concentration, optimal temperature, and $\mathrm{G}+\mathrm{C}$ content on the renaturation rate were determined. Gillis et al. (20) applied the method to the determination of the genome size of 40 different bacteria. The method appeared to offer advantages in terms of simplicity, rapidity, and reproducibility over methods previously described (5, $18,42)$, and for these reasons it was chosen for use in this study.

Renaturation rates may also be used to determine the degree of base sequence homology between DNAs. If two identical DNAs are allowed to reassociate under optimal conditions in the same incubation mixture, the reassociation rate of the mixture is expected to be the same as if they were incubated separately. If two DNAs with no base sequences in common are allowed to reassociate, the reassociation rate is expected to be equal to the sum of their rates when incubated separately. Thus, a mixture of two DNAs with partial base-sequence similarity will exhibit a rate of reassociation somewhere in the range between their rate alone and the sum of their rates. This spectrophotometric technique for determining the degree of DNA-DNA hybridization has been discussed both by Seidler and Mandel (34) and by De Ley et al. (16). Seidler and Mandel (34) based their hybridization procedure on the $C_{0} t$ technique developed by Britten and Kohne (7) and Wetmur and Davidson (42), whereas De Ley et al. (16) proceeded on the initial rate of reassociation concept, which was developed by Gillis et al. (20). We have applied the latter procedure to the hybridization studies presented in this paper because both genome size and degree of hybridization can be combined in the same experiment. In addition, there is no need to employ radiolabeled DNA, and the procedure is simple, rapid, and reproducible. Although the membrane filter (18) and hydroxyapatite hybridization procedures $(5,6)$ may permit a somewhat more detailed examination of the DNA relationships involved, the initial rate method employed here satisfied our immediate purposes of (i) distinguishing between species and groups within spe- cies, confirming relationships previously detected by serological means, and (ii) sorting new isolates into discrete groups, each closely related to an established species. The search for minor differences among strains of a given species is beyond the scope of this paper and would require somewhat different methods.

The typhus biogroup of the genus Rickettsia is currently recognized as containing three species: $R$. prowazekii, $R$. mooseri $(R$. typhi), and $R$. canada (41). In this study we have compared various strains of $R$. prowazekii, $R$. mooseri, and $R$. quintana, both within and without the genus and species boundaries, using the criteria of DNA base ratio, genome size, and degree of DNA-DNA hybridization. We did not include $R$. canada, a recent addition to the genus Rickettsia $(3,29)$, because plaque-purified cultures of this species were not yet available. Extraneous agents were present in the original seed obtained from the American Type Culture Collection, probably as a consequence of multiple egg passages. R. canada will, however, be included in a future study when an adequately purified culture is available.

The genome sizes found among the various strains of $R$. prowazekii, $R$. mooseri, and $R$. quintana are, in general, quite similar and are approximately $10^{9}$ daltons. The validity of the genome size data is supported by the following. (i) The mean value of $2.4 \times 10^{9}$ daltons for the $E$. coli K-12 genome agrees well with the value obtained by Gillis et al. (20), who established the initial renaturation rate method for genome size determination. (ii) The value of $1.0 \times 10^{9}$ daltons obtained for the Fuller strain of $R$. quintana agrees reasonably well with the figure of $9.3 \times 10^{8}$ daltons given by Kingsbury (22). (iii) The molecular weight values obtained for the several strains of $R$. prowazekii and $R$. mooseri compare closely among themselves; no significant molecular weight differences would be expected betweer strains of the same species. (iv) Based on the studies of De Ley et al. (16) involving the effect of the molecular weight of the DNA fragments on the renaturation rate, our average value, from three samples, of $2.5 \times 10^{5}$ daltons compared to the value obtained by De Ley et al. (16), $4 \times 10^{5}$ daltons, is not sufficiently different to affect appreciably the renaturation rate.

Genome size data are now available on $R$. prowazekii, $R$. mooseri, and $R$. quintana (this paper) and on $R$. rickettsii and $R$. quintana (22), and all have approximately the same value $\left(10^{9}\right.$ daltons). $R$. prowazekii, $R$. mooseri, and $R$. rickettsii are categorized as obligately intracellular parasites, whereas $R$. quintana grows extracel- 
lularly in the louse gut, in tissue culture, and on a blood agar medium $(39,41)$. Similarly, Kingsbury (22) obtained the same genome size for $R$. rickettsii as compared to Neisseria gonorrhoeae and Neisseria meningitidis. Thus, the genome sizes of a significant proportion of rickettsial species are well within the genome sizes of certain free-living bacteria and are, in fact, significantly larger than the genome size of members of the genus Mycoplasma $\left(5 \times 10^{8}\right.$ daltons) (1). If one accepts the dogma that essentially the entire bacterial genome codes for structural proteins, enzymes, and several types of ribonucleic acid and that there is little or no redundancy in the code (procaryotes), then one must assume that the failure of rickettsiae to grow extracellularly is not due to a genome size too small to be able to code for the essentials of extracellular growth but, rather, may be due to a relatively small number of evolutionary adaptations to a host-cell dependency.

The organisms of the typhus group included in this study had been identified as strains of one or the other reference organisms, $R$. prowazekii Breinl or R. mooseri (R. typhi) Wilmington, on the basis of conventional biological and serological criteria. The strains studied here had been isolated from a variety of sources, diverse geographical locations, and widely separated points in time and had had very different passage histories in the laboratory. Nonetheless, a remarkably high degree of hybridization (mean $97 \%$, with a range of 92 to $104 \%$ ) was found among the DNAs of strains identified on the basis of such conventional criteria as $R$. prowazekii and among DNAs of strains which had been identified as $R$. mooseri. Thus, as with conventional phenotypic characters, DNA hybridization values clustered tightly around the respective reference strains, with a range far less than that observed by others with certain different bacterial species $(12,17,35)$. The DNA hybridization method employed here is not sensitive enough to detect minor differences among closely related strains. That some intraspecific differences may exist, however, is suggested by the studies of Dasch et al. (13), who recently studied the intraspecies differences of a number of strains classified as either $R$. prowazekii or $R$. mooseri by conventional criteria and who showed that the sodium dodecyl sulfate-polyacrylamide gel electrophoresis technique revealed no discernible differences between the $R$. prowazekii strains (Breinl [virulent], flying squirrel strains [four isolates], and Madrid E [avirulent, antibiotic resistant]) or between two $R$. mooseri isolates (Wilmington [human isolate] and a rat isolate). Dasch et al. (13), using the technique of isoelectric focusing of soluble rick- ettsial extracts, were, however, able to demonstrate some minor strain differences within $R$. prowazekii. These differences, in general, involved only a single protein band. The two strains of $R$. mooseri showed no discernible difference using this same technique (13).

The recent, rather startling, evidence that several strains of rickettsia-like organisms isolated from flying squirrels (Glaucomys volans volans) are in fact Rickettsia prowazekii warrants further discussion. The original isolations and subsequent serological studies were reported by Bozeman et al. (4) in 1975. Since then Woodman et al. (45), using the criteria of plaque morphology, erythromycin susceptibility, hemolytic activity, and glutamate oxidation, which of course are not discriminating criteria, showed the biological similarity of these flying squirrel strains to several established $R$. prowazekii strains. Dasch et al. (13) employed a number of additional criteria, including sodium dodecyl sulfatepolyacrylamide gel electrophoresis and isoelectric focusing of proteins and the ratios of activities of several enzyme systems, to study the same flying squirrel-typhus relationship. These latter studies gave further support to the view that these flying squirrel strains are indeed members of $R$. prowazekii; in the study reported here we give additional confirmation. The $\mathrm{G}+\mathrm{C}$ content (29.5 $\mathrm{mol} \%)$ of the DNA of the one flying squirrel strain studied is the same as those of recognized $R$. prowazekii strains. In addition, the flying squirrel strain gave hybridization values approximating $100 \%$ against the Breinl, Madrid E, and Burundi strains of $R$. prowazekii.

The criteria for establishing different species among the rickettsiae are poorly defined. Most recently, the organisms that cause louse-borne epidemic typhus fever and those that cause murine typhus fever have been assigned to different species, viz., $R$. prowazekii and $R$. mooseri, respectively, on the basis of a complex array of biological, epidemiological, and serological criteria (41). The DNA hybridization studies reported here show that, while the DNAs of strains classified as one species or the other on the basis of these conventional criteria hybridize to almost $100 \%$ within the respective species, the degree of hybridization between the DNAs of strains of the two species is consistently only 70 to $77 \%$. Thus, the strains all clearly fell into one or the other group tightly clustered about the respective reference strains, with no strains with intermediate values.

The degree of differences in DNAs, as revealed by hybridization studies, necessary to relegate organisms to different species remains an arbitrary matter (26). When compared with the experience of others with other bacterial 
groups $(5,33)$, the differences observed here appear to fall in an intermediate zone, sufficiently large to indicate species differences from some bacteria but not from others. In the case of the typhus rickettsiae studied here, the clear separation of strains into two DNA-DNA hybridization groups with no intermediate values might be taken as evidence that the 70 to $77 \%$ hybridization between the two groups does indeed constitute the basis for two species. Moreover, limited protein profile studies of purified rickettsiae have been performed in recent years by several investigators using the sodium dodecyl sulfate-polyacrylamide gel electrophoresis techniques. The consensus is that, although there is a general similarity in the protein profiles of strains of the species $R$. prowazekii and $R$. mooseri, there are too many differences observed to consider them as different strains of the same species $(13,19,32)$.

It would appear, then, that the total available biological, serological, protein profile, and DNADNA hybridization information is consistent with the current classification of typhus rickettsiae into the two species $R$. prowazekii and $R$. mooseri. The relationship of $R$. canada to these two species will be the subject of a separate study.

We included strains of the agent of trench fever in this study primarily as a kind of negative control for the methodology. This organism was formerly included in the genus Rickettsia, but more recently it has been moved to a new genus on the basis of certain unique phenetic characteristics, and it is now designated Rochalimaea quintana (41). It does, however, display certain metabolic similarities to typhus group rickettsiae (41).

The accuracy of the initial rate method employed here suffers when the $\mathrm{G}+\mathrm{C}$ content of the two DNAs differs by more than $8 \%$ (16). However, the degree of hybridization observed (25 to $33 \%$ ) between the DNAs of $R$. quintana and $R$. prowazekii Breinl and $R$. mooseri Wilmington is within the maximum percent DNA homology between two DNA types which differ by 9 to $10 \%$ in $\mathrm{G}+\mathrm{C}$ content but which have equal molecular weights and an average compositional nucleotide distribution (15). Thus, despite the limitations of the method, the results obtained are compatible with current views on the taxonomic relationship between $R$. quintana and the typhus rickettsiae (40). A more detailed study of $R$. quintana strains and Baker's vole agent appears elsewhere (31).

\section{ACKNOWLEDGMENTS}

This study received support from contract DADA 17-71-C. 1007 with the U.S. Army Medical Research and Development
Command, Office of the Surgeon General, Department of the Army.

We acknowledge the excellent technical assistance given by Dena Grossman, Anna Waddell, and MayBritt Doelp and the assistance given by D. J. Silverman in the electron microscopy of DNA fragments.

\section{REPRINT REQUESTS}

Address reprint requests to: Dr. William F. Myers, Department of Microbiology, University of Maryland School of Medicine, Baltimore, MD 21201.

\section{LITERATURE CITED}

1. Bak, A. L., F. T. Black, C. Christiansen, and E. A. Freundt. 1969. Genome size of mycoplasmal DNA. Nature (London) 224:1209-1210.

2. Bovarnick, M. R., and J. C. Miller. 1950. Oxidation and transamination of glutamate by typhus rickettsiae. $J$. Biol. Chem. 184:661-676.

3. Bozeman, F. M., B. L. Elisberg, J. W. Humphries, K. Runcik, and D. B. Palmer, Jr. 1970. Serologic evidence of Rickettsia canada infection in man. J. Infect. Dis. 121:367-371.

4. Bozeman, F. M., S. A. Masiello, M. S. Williams, and B. L. Elisberg. 1975. Epidemic typhus rickettsiae isolated from flying squirrels. Nature (London) 255:545547.

5. Brenner, D. J. 1975. Deoxyribonucleic acid reassociation in the taxonomy of enteric bacteria. Int. J. Syst. Bacteriol. 23:298-307.

6. Brenner, D. J., and S. Falkow. 1971. Molecular relationships among members of the Enterobacteriaceae. Adv. Genet. 16:81-118.

7. Britten, R. J., and D. E. Kohne. 1966. Nucleotide sequence repetition in DNA. Carnegie Inst. Yearb. 65:78106.

8. Burton, K. 1956. A study of the conditions and mechanism of the diphenylamine reaction for the colorimetric estimation of deoxyribonucleic acid. Biochem. J. 62: 315-323.

9. Cahn, F. H., and M. S. Fox. 1968. Fractionation of transformable bacteria from competent cultures of $B a$. cillus subtilis on Renografin gradients. J. Bacteriol. 95: 867-875.

10. Christiansen, C., E. A. Freundt, and F. T. Black. 1975 Genome size and deoxyribonucleic acid base composition of Thermoplasma acidophilum. Int. J. Syst. Bacteriol. 25:99-101.

11. Clavero, G., and F. P. Gallardo. 1943. Estudio experimental de una cepa apatógena e immunizante de Rick. ettsiae prowazeki Cepa E. Rev. Sanid. Hig. Publica 17: $1-27$.

12. Coykendall, A. L., and A. J. Munzenmaier. 1978. Deoxyribonucleic acid base sequence studies on glucanproducing and glucan-negative strains of Streptococcus mitior. Int. J. Syst. Bacteriol. 28:511-515.

13. Dasch, G. A., J. R. Samms, and E. Weiss. 1978. Biochemical characteristics of typhus group rickettsiae with special attention to the Rickettsia prowazekii strains isolated from flying squirrels. Infect. Immun. 19: 676-685.

14. Dasch, G. A., and E. Weiss. 1977. Characterization of the Madrid E strain of Rickettsia prowazekii purified by Renografin density gradient centrifugation. Infect. Immun. 15:280-286.

15. De Ley, J. Compositional nucleotide distribution and the theoretical prediction of homology in bacterial DNA. J. Theor. Biol. 22:89-116.

16. De Ley, J., H. Cattoir, and A. Reynaerts. 1970. The quantitative measurement of DNA hybridization from renaturation rates. Eur. J. Biochem. 12:133-142. 
17. Dellaglio, F., V. Bottazi, and M. Vescovo. 1975. Deoxyribonucleic acid homology among Lactobacillus species of the subgenus Streptobacterium Orla-Jensen. Int. J. Syst. Bacteriol. 25:160-172.

18. Denhardt, D. T. 1966. A membrane-filter technique for the detection of complementary DNA. Biochem. Biophys. Res. Commun. 23:641-646.

19. Eisemann, C. S., and J. V. Osterman. 1976. Proteins of typhus and spotted fever rickettsiae. Infect. Immun. 14: $155-162$.

20. Gillis, M., J. De Ley, and M. DeCleene. 1970. The determination of molecular weight of bacterial genome DNA from renaturation rates. Eur. J. Biochem. 12:143153.

21. Karp, A. 1954. An immunological purification of typhus rickettsiae. J. Bacteriol. 67:450-455.

22. Kingsbury, D. T. 1969. Estimate of the genome size of various microorganisms. J. Bacteriol. 98:1400-1401.

23. Kleinschmidt, A. D., D. Lang, D. Jacherts, and R. K. Zahn. 1962. Darstellung und Längemessungen des gesamten Desoxyribonucleinsaureinhaltes von $T_{2}$ Bacteriophagen. Biochim. Biophys. Acta 61:857-864.

24. Landgridge, R., and H. R. Wilson. 1960. The molecular configuration of deoxyribonucleic acid. J. Mol. Biol. 2: 19-37.

25. Lowry, O. H., N. J. Rosebrough, A. L. Farr, and R. J. Randall. 1951. Protein measurement with the Folin phenol reagent. J. Biol. Chem. 193:265-275.

26. Mandel, M. 1969. New approaches to bacterial taxonomy: perspective and prospects. Annu. Rev. Microbiol. 23: 239-274.

27. Marmur, J., and P. Doty. 1962. Determination of the base composition of deoxyribonucleic acid from its thermal denaturation temperature. J. Mol. Biol. 5:109-118.

28. Maxcy, K. F. 1929. Endemic typhus of the southeastern United States: reaction of the guinea pig. Public Health Rep. 44:598-600.

29. McKiel, J. A., E. J. Bell, and D. B. Lackman. 1967. Rickettsia canada: a new member of the typhus group of rickettsiae isolated from Haemophysalis leporispalustris ticks in Canada. Can. J. Microbiol. 13:503-510.

30. Meijbaum, W. 1939. Estimation of small amounts of pentose especially in derivatives of adenylic acid. $\mathrm{Z}$. Physiol Chem. 258:117-120.

31. Myers, W. F., C. L. Wisseman, Jr., P. Fiset, E. V. Oaks, and J. F. Smith. 1979. Taxonomic relationship of vole agent to Rochalimaea quintana. Infect. Immun. 26:976-983.

32. Obijeski, J. F., L. Palmer, and T. Tzianabos. 1974. Proteins of purified rickettsiae. Microbios 11:61-67.
33. Page, L. R., and G. N. Krywolap. 1976. Determination of the deoxyribonucleic acid composition and deoxyribonucleic acid-deoxyribonucleic acid hybridization of Fusobacterium fusiforme, Fusobacterium polymor. phum, and Leptotrichia buccalis: taxonomic considerations. Int. J. Syst. Bacteriol. 26:301-304.

34. Seidler, R. J., and M. Mandel. 1971. Quantitative aspects of deoxyribonucleic acid renaturation: base composition, state of chromosome replication, and polynucleotide homologies. J. Bacteriol. 106:608-614.

35. Seki, T., C. K. Chung, H. Mikami, and Y. Oshima. 1978. Deoxyribonucleic acid homology and taxonomy of the genus Bacillus. Int. J. Syst. Bacteriol. 28:182-189.

36. Thomas, Jr., C. A., K. I. Berns, and T. J. Kelly, Jr. 1966. Isolation of high molecular weight DNA from bacteria and cell nuclei, p. 535-539. In G. L. Cantoni and D. R. Davies (ed.), Procedures in nucleic acid research. Harper \& Row, Publishers, New York.

37. Tyeryar, F. J., Jr., E. Weiss, D. B. Millar, F. M. Bozeman, and R. A. Ormsbee. 1973. DNA base composition of rickettsiae. Science 180:415-417.

38. Varela, G., J. W. Vinson, and C. Molina-Pasquel. 1969. Trench fever II: propagation of Rickettsia quintana on cell-free medium from the blood of two patients. Am. J. Trop. Med. Hyg. 18:708-712.

39. Vinson, J. W., and H. S. Fuller. 1961. Studies on trench fever. I. Propagation of rickettsia-like microorganisms from a patient's blood. Pathol. Microbiol. 24(Suppl.): $152-166$.

40. Weiss, E., J. C. Coolbaugh, and J. C. Williams. 1975 Separation of viable Rickettsia typhi from yolk sac and $\mathbf{L}$ cell host components by Renografin density gradient centrifugation. Appl. Microbiol. 30:456-463.

41. Weiss, E., and J. W. Moulder. 1974. Genus I. Rickettsia da Rocha-Lima 1916, nom. gen. cons. opin. 19, Jud. Comm. 1958, p. 883-890. In R. E. Buchanan and N. E. Gibbons (ed.), Bergey's manual of determinative bacteriology, 8th ed. The Williams \& Wilkins Co., Baltimore.

42. Wetmur, J. G., and N. Davidson. 1968. Kinetics of renaturation of DNA. J. Mol. Biol, 31:349-370.

43. Wisseman, C. L., Jr. 1973. DNA composition in Rickettsia mooseri by base analysis. Acta Virol. 17:443.

44. Wolbach, S. B., J. L. Todd, and F. W. Palfrey, 1922 The etiology and pathology of typhus. Harvard University Press, Cambridge, Mass.

45. Woodman, D. R., E. Weiss, G. A. Dasch, and F. M. Bozeman. 1977. Biological properties of Rickettsia prowazeki strains isolated from flying squirrels. Infect. Immun. 16:853-860. 